\title{
ESTUDIOS
}

\section{La Metáfora Erótica: \\ Góngora, Joaquín Belda y Lezama Lima}

"Escribir sobre Paradiso-dice Julio Ortega-es una empresa condenada de antemano a la insuficiencia porque esta enorme novela es prácticamente irreductible a la imagen de un proceso o una estructura que la crítica presume revelar en los textos"'. 1

La observación no puede ser más justa: el ensayista que se encara con la obra monumental de Lezama tropieza con un obstáculo de la misma indole que el propio novelista señala a propósito de su maestro Góngora. "Los acercamientos a don Luis-dice-han sido siempre de sabios de Zalamea. Pretenden oponer malicia crítica a su verbal sucesión y enjalbegada seriedad a sus malicias. Pretenden leerlo críticamente y piérdenle el tropel, sus remolinos y desfiles". 2 Para el lector habitual de novelas Paradiso es un magma verbal, una obra sin pies ni cabeza en la que la acción argumental se pierde en un piélago de palabras y frases larguísimas, que se entienden como lianas interminables o se ramifican hasta adquirir una frondosidad boscosa. Dicho lector se contenta con leer por lo común el célebre capítulo VIII y decreta que el resto no merece la pena. Algunos de los comentarios que he oído me recuerdan a los que tres siglos y medio atrás saludaron la aparición de una obra con la que Paradiso mantiene muchos puntos de contacto: me refiero a Soledades. Escuchemos, por ejemplo, al humanista Francisco Cascales: "¡Oh diabólico poema! Pues qué ha pretendido nuestro poeta? Yo lo diré: destruir la poesía (...) En qué manera? Volviendo a su primer caos las cosas; haciendo que ni los pensamientos se entiendan, ni las palabras se conozcan con la confusión y desorden". Desde el punto de vista de Cascales, tan próximo al de los antivanguardistas de hoy, Soledades es una especie de Babel, un delirio de lenguaje motivado por la incorregible vanidad del poeta. Sus alusiones, imágenes y artificios sintácticos se le antojan "inútiles y nugatorios"; sólo sirven "de dar garrote al entendimiento", El Góngora de Soledades y Polifemo, concluye, es el "Mahoma de la poesía española", 3

I Relato de la utopta. Notas sobre la narrativa cubana de la Revolucion (Barcelona: Ed. Lumen, 1972).

2 "Sierpe de don Luis de Góngora", en Orbita de Lezama Lima (La Habana: Ed. UNEAC, 1966).

3 Cartas filologicas. Inútil decir que la referencia al profeta del Islam es el máximo insulto en el pervertido contexto español de la época. 
El aspecto macizo de la prosa de Lezama, su sensación de impenetrabilidad han suscitado en los últimos años reacciones parecidas. Al enfrentarse a obras como Paradiso los críticos realista-conservadores hablan siempre de "caos" y arguyen que la Novela está en peligro-asimilando al tipo de novelas que defienden y estiman a la Novela en general como los burgueses hablan de "confusión" y "desorden" al mencionar la lucha de los grupos revolucionarios, y en lugar de decir que ponen en peligro a la sociedad burguesa, afirman que ponen en peligro a la Sociedad. Esta identificación del crítico conservador realista con la Novela y del burgués con la Sociedad es, claro está, mero reflejo de su miedo a unas realidades nuevas que no comprenden ni controlan y que amenazan de muerte su pequeño o gran capital de conocimientos o bienes en nombre de una realidad cultural o social diferentes y, a fin de cuentas, más fecundas y vastas.

Hay una infinidad de posibles lecturas de Paradiso: desde la que atienda al "contenido" espiritual del texto a la que centre su atención en las "figuras" alegóricas que se dibujan mediante una lectura oblícua-como esos grabados cuya estructura emerge tan sólo desde un determinado ángulo de visión y en los que descubrimos una "escena" o "cuadro", allí donde a primera vista no había sino un amasijo de líneas. Teniendo en cuenta los límites de brevedad del presente ensayo, centraré principalmente mi atención en el elemento primordial de la novela, esto es, el lenguaje, sin descuidar del todo la existencia de un sistema distinto de la lengua, situado en el nivel del relato-me refiero al discurso narrativo.

A dicho nivel, Paradiso se presenta, en apariencia, como un híbrido de bistoire y discours, donde el autor, como típico novelista del XIX, pasa con la mayor naturalidad del mundo de un sistema a otro, intercalando comentarios, juicios, digresiones que revelan a cada paso su presencia omnisciente hasta el extremo de que, si bien en la novela se emplea la tercera persona gramatical, Lezama infringe despreocupadamente la regla de mantenerse fiel al enfoque elegido y asoma la nariz o la cabeza entera mediante frecuentes incursiones en la primera persona del singular o plural. A menudo interrumpe el relato para comunicarnos alguna información sobre el procedimiento narrativo que sigue: "El hermano de la señora Rialta, que ya exigirá, de acuerdo con su peculiar modo, penetrar en la novela..." Esa noche (...) a la que vamos a aludir por merecer un acompañamiento especial..." "El padre de José Cemí, a quien vimos en capitulos anteriores dentro de las ordenanzas y ceremoniales de su jerarquía de coronel, lo vamos a ir descubriendo en su niñez, hasta su encuentro con la familia Rialta..." Estos "signos del autor" responden de modo obvio a una intención irónica: el empleo deliberado de un recurso viejo, gastado hasta la urdimbre, como si Lezama quisiera indicarnos que la trama novelesca es un simple pretexto y lo que interesa a él es otra cosa. Con todo, los numerosos elementos característicos de la novela del XIX se entreverán con otros de signo opuesto: así, en vez de buscar una motivación realista a los encuentros "casuales" de los personajes, sigue el procedimiento pre-cervantino del encuentro puramente funcional, de acuerdo con las exigencias de la intriga. En el capítulo XIII, por ejemplo, Martincillo Vivo, Adalberto Kuller, José Cemí y Oppiano Licario "coinciden" por vías diferentes en un ómnibus - aunque la funcionalidad aquí reviste un aspecto simbólico: el encuentro de Cemí con su propio destino. Por otra parte, Lezama presenta a los personajes desde un 
prisma resueltamente anti-realista. Todos los héroes de "paradiso", desde el cocinero Juan Izquierdo a Oppiano Licario, parecen poseídos de la missıa pasión metafórica, cultista y barroca que el autor. Reprochárselo a Lezama sería tan impertinente y ridículo como reconvenir a Melibea por su florida erudición greco-latina en la escena de su suicidio o echar en cara a los personajes de Shakespeare, Calderón o Racine el hecho de expresarse en verso.

Poeta metido a novelista, Lezama descubre sin cesar la existencia de vasos comunicantes entre los dos géneros. Tomemos, por ejemplo, la noción de "héroe novelesco": en vez de los personajes transitivos del común de las novelas, los protagonistas de Paradiso desempeñan casi siempre un papel pasivo, meramente receptor. Su destino se resuelve desde fuera, en virtud de fuerzas enigmáticas, que escapan a su control. Los acontecimientos que llueven sobre ellos tienen un doble sentido: a la vez literal y alegórico. La búsqueda de Cemí es la búsqueda del código secreto que orienta sus pasos hacia su nacimiento como escritor. Todos los hechos que acaecerán en su vida tendrán así indefectiblemente una dimensión suprarreal que él deberá interpretar. Si examinamos Paradiso con atención descubriremos que la actitud de sus héroes desconoce el tiempo verbal activo: Cemí, Fronesis, Oppiano Licario son impulsados por corrientes misteriosas que les llevan a cumplir un destino que ignoran. La causalidad dominante en la novela-esto es, la lógica de sus acciones-no es sicológica o factual, sino simbólica. Aunque Lezama emplee la tercera persona gramatical y el tiempo verbal pasado propios de la novela, el personaje de Cemi está mucho más cerca del "yo" del poeta que del "el" del narrador:

sintió que una imantación guiaba su mirada...

la imagen, más que la marcha, lo iban guiando a la escuela...

Una casa de tres pisos (...) lo tironeó con su hechizo sibilino...

Sentía que la fuerza impelente del patio de su casa se había extinguido en él, pero que al mismo tiempo había nacido, para reemplazar a la anterior, una fuerza de absorción, especialmente constituida para atraerlo a su centro absorbente o de imantación.

La comunicación fluida entre los dos géneros se advierte con mayor claridad aún en el uso lezamesco del lenguaje. En su novela, Lezama evita el malthusianismo verbal inherente a la comunicación ordinaria en nombre de la deliberada opacidad del lenguaje poético. Frente a la "transparencia" del lenguaje meramente denotativo, los tropos e imágenes del poeta reafirman la existencia de una expresión lingüistica perceptible en sí misma y no como simple intermediario de su significación. El búho no será búho, sino "grave, de perezosas plumas globo"'; el halcón, el "raudo torbellino de Noruega". Como el propio Lezama dice de Góngora, " "tenía principalmente de los árabes el secreto deseo (...) de sensualizar el verso, convirtiéndolo en corpúsculo”. El poeta reemplaza así al lenguaje transparente con el lenguaje figurado para imponer la presencia de las palabras - al lenguaje común con el lenguaje literario para imponer la presencia de las cosas. ${ }^{4}$ Como vamos a ver,

4 Cf. Tzvetan Todorov, Théorie de la littérature (Paris: Ed. Seuil, 1966). 
la expansión del lenguaje de Paradiso emula con la realidad y la sustituye con un cuerpo verbal; es decir, se apropia del mundo exterior mediante el mecanismo proliferante de la metáfora. En un pasaje bellísimo de la novela, Lezama nos explica el origen de dicho mecanismo en la mente del niño Cemí, cuando su padre le muestra dos láminas que representan respectivamente un bachiller y un amolador:

La ávida curiosidad adelantaba el tiempo de precisión de los grabados, y José Cemí detuvo con su apresurada inquietud el indice en el grabado del amolador, al tiempo que oía a su padre decir: el bachiller. Así cuando días más tarde su padre le dijo:- ¿Cuando tengas más años querrás, ser bachiller? ¿Qué es un bachiller?-Contestaba con la seguridad de quien ha comprobado sus visiones.- Un bachiller es una rueda que lanza chispas, que a medida que la rueda va alcanzando más velocidad, las chispas se multiplican hasta aclarar la noche.-Como quiera en ese momento su padre no podía precisar el trueque de los grabados en relación con la voz que explicaba, se extrañó del raro don metafórico de su hijo. De su manera profética y simbólica de entender los oficios.

La obsesión analógica de Lezama procede de dos maneras: por lo general, parte de la desemejanza para reunir, gracias al poder vinculador de la palabra, dos series semánticas totalmente dispares, o bien, con menor frecuencia, recurre a la metonimia, mediante la. asociación por contigiiidad, anexionando en este caso el objeto más próximo:

La brisa tenía algo de sombra, la sombra algo de hoja, la hoja mordida en sus bordes por la iguana columpiaba de nuevo a la noche. La noche agarraba por los brazos, sostenía en su caida al reloj de pared, dividía el cuerpo de la harina con su péndulo de obsidiana. Cemí sentía la claridad lunar delante que oscilaba como la silueta del pájaro Pong, desde el mar hasta la caparazón de la tortuga negra.

Metonimias y metáforas proliferan con espléndida-suntuosidad barroca y adquieren en el curso de su acelerado progreso una existencia autónoma. El propio Lezama ha descrito agudamente este avance irresistible de los símiles cuando examina el mecanismo cognoscitivo de Oppiano Licario:

Partía de la cartesiana progresión matemática. La analogía de dos términos de la progresión desarrollaba una tercera progresión o marcha hasta abarcar el tercer punto de desconocimiento. En los dos primeros términos pervivía aún mucha nostalgia de la sustancia extensible. Era el hallazgo del tercer punto desconocido, al tiempo de recobrar, el que visualizaba y extraía lentamente de la extensión la analogia de los dos primeros móviles.

En Paradiso una palabra convoca a otra y la reunión de ambas origina una tercera. Como ha captado muy bien Julio Ortega este proceso metafórico resume y ejemplariza el método de composición: "un personaje supone a otro y ambos a un tercero. La mirada aproxima un objeto a otro y entre ellos imponen una nueva figura (...), un episodio suscita otro episodio en una sucesiva transformación hiperbólica''. Todo acontecimiento, decíamos, tiene para José Cemí un sentido literal y otro alegórico.Lezama no suprime uno de los términos de la oposición, antes bien los mantiene en una nerfecta simultaneidad que contradice las reglas del pensamiento lógico. La mente de Cemí abarca los dos términos y tiende un puente metafórico entre ellos. Como don Quijote, vive la metáfora desde dentro-esto es, - se metaforiza él mismo. 
La utilización del excedente significativo de las palabras-de su plusvalía verbal-permite a Lezama establecer una compatibilidad semántica de signos no relacionados anteriormente entre sí: las palabras muertas del diccionario cobran vida, se agrupan sensualmente delante de nosotros, dibujan figuras exquisitas en el blanco de la página, se transmutan en "cuerpo"' como en la poesía árabe. Gracias a este mecanismo extensivo cualquier frase anodina se ramifica de modo infinito. El índice trastocador de Lezama es realmente prodigioso: mezcla las relaciones temporales con las espaciales; suprime o modifica la distancia que separa a un objeto de otro haciendo que se fundan en deslumbradora metonimia o se descompongan en brillante sinécdoque; trastorna la sucesión temporal y proyecta lo pasado hacia lo futuro y lo futuro hacia lo pasado. El orden de prioridades del novelista sufre igualmente una alteración profunda: mientras la muerte de tío Alberto es descrita en tres líneas las décimas del guitarrista que la preceden ocupan varias páginas. Dicha subversión es un ingrediente composicional de primer orden en la estructura total de Paradiso y se manifiesta inclusive en una nueva configuración de los personajes:

La vieja Mela extendía una gorgona sobre los nódulos del tiempo. (...) Sus noventa y cuatro años parecían bastoncillos en manos de gnomos criados por el Conde de Cagliostro. Como en algunos pintores los objetos adelantándose a su espacial adecuación, el tiempo se había escapado de su sucesión para situarse en planos favoritos, tiránicos, como si Proserpina y la polis actual se prestaran figuras con tan doméstica cordialidad que no presentasen las asimetrias de su extracción, los lamentos de su errancia evaporada.

En Lezama, todo símil engendra una serie causal en la que el vínculo importa más que los objetos que relaciona, hasta el extremo de borrarlos. Paradiso crea un sistema de afinidades electivas que abraza a un tiempo el mundo de la naturaleza y el de la cultura. El registro de sus figuras de lenguaje es amplísimo tanto cuanto el novelista singulariza casi siempre los objetos al arrancarlos de su propia serie semántica proyectándolos a una serie heterogénea. Tal mecanismo le conduce a apropiarse de elementos de todas las culturas-a saquear, por así decirlo, hechos, datos, realidades de la geografia y pintura, historia y ciencias naturales. No existe aún, que yo sepa, un repertorio detallado de los símiles y tropos de Paradiso. En el único que conozco ${ }^{5}$, su autora distingue: las metáforas e imágenes relacionadas con el mundo clásico; las que enlazan con lo que denomina un "cosmopolitismo histórico"'; las que hacen referencia a una "geografia exótica"; las que encadenan con el mundo animal y componen el magnifico bestiario de la novela. En general, la clasificación me parece acertada, si bien cabe incluir a los dos primeros grupos en un único y vasto repertorio histórico-cultural. Por mi parte, yo añadiría una nueva serie: la de las asociaciones estrictamente insólitas, peculiares de la poesía surrealista, aunque, en este caso, se remonten, con mayor exactitud, al universo de Góngora.

En los tres primeros grupos de la nueva clasificación, los símiles del novelista descubren que su imaginación poética parece haberse alimentado en gran parte de grabados de manuales de historia y "geografía pintoresca", libros de arte ilustrados, dibujos de enciclopedias. Dichas obras, leídas en los años del colegio, despertaron sin duda la sen-

\footnotetext{
5 Esperanza Figueroa Amaral, "Forma y estilo en Paradiso", RI, XXXVI, 72, jul-sept., 1970, pp. 425-435.
} 
sualidad y apetito cognoscitivo del joven Lezama como despertaron más tarde los míos-aunque en mi caso la impresión erótica causada por las láminas de Ciencias Naturales y sus referencias al bestiario fue mucho mayor que la de los, para mí, fríos insípidos desnudos del arte griego. Láminas, probablemente en color, ya de libros de historia o pintura.

Alzada su mano derecha, como en una'alegoría del Siglo XVIII (...) como si en una de esas sociedades secretas de la época del iluminismo, se diese la consigna al recibir la visita de incógnito de Benjamin Franklin...

Resoplaba como un fuelle de mano de un alquimista de la escuela de Nicolás Flamel.

El tiempo (agrandaba) la figura hasta darle la contextura de un Desmoulins, de un Marat con los puños cerrados, golpeando las variantes, los ecos, o el tedio de una asamblea termidoriana.

Bajó la escalera con la mayestática decisión de quien tiene que cumplir una fatal obligación, muy digna, con su nieto un poco delante, y los dos nietos a su lado. Pura composición Velazqueña.

En algunas mesas muchachas de pronunciado pecho potente intercambiaban sonrisas y melindres con jóvenes que parecían en acecho para la caza del unicornio, entre la fuente y las enaguas de una princesita de Westfalia.

El inviernillo caracoleaba como un alazán cabalgado por el niño infante Baltasar.

Impensadas bagatelas, abiertas de pronto como un quitasol en un desembarco imperial en Túnez.

Ya de manuales de geografía humana:

parecía uno de esos gigantes del oeste de Europa, que con mallas de decapitador, alzan en los circos rieles de ferrocarril y colocan sobre uno de sus brazos extendidos un matrimonio obrero con su hija tomándose un mantecado.

...hierático como un vendedor de cazuelas en el Irán.

...toda la ropa sobre el brazo derecho parecía convertirlo en un ladronzuelo de un mercado de Esmirna.

...metamorfosear el alacrán en palomo comiendo maíz en la palma de la mano de un veneciano.

...para librarse de una rastra agrandada como un cortejo de consagración en Bombay. 
Ya de animales representados en un texto escolar de zoología:

...su acecho era el de un félida reparando con lentitud asombrosa los yerbazales para caer sobre la presa.

...misteriosos y raros como el zorro azul corriendo por las estepas siberianas.

...en una modorra semejante a la de un osillo perezoso en un parque londinenese. Este influjo visual no es una simple impresión personal mía, y a él parece aludir el propio Lezama Lima cuando, al comentar en uno de sus ensayos la obra pictórica de Van Eyck y Simone Martini, escribe estas líneas: "en todas estas láminas hemos extraído presencias naturales y datos de cultura-que actúan como personajes, que participan como metáforas." 6

Un cuarto grupo de símiles-insisto en que no se trata de una clasificación exhaustiva sino de una ordenación orientadora-comprende todos aquéllos que se fundan en una asociación extraña, deliberadamente paradójica: en el chispazo creador ocasionado por el contacto de dos elementos pertenecientes a series totalmente heterogéneas. "La metáfora lezamesca-dice Severo Sarduy en su magnifico "Homenaje" al autor ${ }^{7}$-llega a un alejamiento tal de sus términos, a una libertad hiperbólica que no alcanza en español más que Góngora. Aquí el distanciamiento entre significante y significado, la falla que se abre entre las faces de la metáfora, la amplitud del como es máxima:

...sentía como si por su región cerebelosa pasase un cometa gobernado por el vozarrón de un enano borgoñón.

...bigotillos de foca que sobre una mesa otomana retoca con su nariz pitagórica de andrógino, las bolas suecas, los gorros del ladrón de la mezquita.

...empuñando una polvera en donde parecía que hervía un periquito.

...la noche caía incesante como si se hubiera apeado de un normando caballo de granja.

...el gato moviendo sus bigotes como si fuera a unir dos palabras.

El mecanismo extensivo opera igualmente en el caso de estas asociaciones insólitas, incluso en el discurso de alguno de los personajes de la novela:

El escolta daba unos pasos rastrillados, polvo escupitajo sus vaquetas rotando, apuntaba al centro de astucia y hundimiento y fijaba la fresa como con la muleta de una momentánea sierpe umbilical. Se impulsaba uno de los presos, daban gritos como pescadores japoneses que rechazaran una escuadra de nobles, y las fresas reventadas, con su linfa sagrada penetrando en la Tebas de sus semillas, se desconchaban a través del paredón, donde muy pronto la llegada del rayo solar

6 “Mitos y cansancio clásico" en La expresion americana (Madrid: Alianza Editorial, 1969).

${ }^{7}$ Escrito sobre un cuerpo (Buenos Aires: Ed. Sudamericana, 1969). 
ordenaba sus transmigraciones misteriosas, ya de pavo en Ceylan, ya de perezoso en un bosque londinense.

La abundancia de imágenes, símiles, circunloquios, figuras, es esencialmente gongorina. Cuando Lezama describe la manifestación universitaria contra la dictadura lo hace en términos de una lucha entre aqueos y troyanos y el dirigente estudiantil es nombrado indirectamente, mediante una sucesión de perífrases. El criado chino de Michelena es "Buñuelo de Oro", "'Doradillo Rápida", "Pasa Fuente Veloz'”, "Bandeja Saltamontes", el cochero de tío Alberto "el malicioso auriga criollo" ; Oppiano Licario, "el mediador, el que le sale al paso a la ananké" ; los divulgadores de la infamia del atleta Baena Albornoz, "los glosadores de Ulpiano, Gallo y Modestino".

"Góngora-escribe Sarduy-es la presencia absoluta de Paradiso: todo el aparato discursivo de la novela, tan complejo, no es más que una parábola cuyo centro-elíptico-es el culteranismo español'. Su observación no puede ser más exacta: el poeta cordobés es, efectivamente, el referente de Paradiso y la novela entera ilustra el mecanismo verbal del máximo creador del Barroco. Unos años antes que Lezama el novelista español Luis Martín Santos había entablado el mismo diálogo intertextual con la obra de Góngora en algunos pasajes de Tiempo de silencio. Pero en Lezama este diálogo adquiere carácter sistemático. La alusión al cordobés es en algunos casos literal o casi literal:

...este si aborto de ovas y lamas.

...levantó más la voz y se le oyó por todo el recinto.

...cuyo diente no perdonó a racimo, aún en la frente de Baco, cuanto más en su sarmiento.

Gongorizando todavía el novelista describe los objetos no con los nombres habituales de los elementos que los componen "sino con palabras tomadas a la descripción de las partes correspondientes en otros objetos" ${ }^{8}$ Cuanto más remotas sean las afinidades entre las dos series, más inusitado será el denominador común que inventa el poeta y tanto más se dislocarán y ramificarán las imágenes o series de imágenes que utiliza. En otras ocasiones, la metáfora gongorina crea felizmente ese "poliedro verbal", ese "cuerpo verbal nadador" que permitirá a José Cemí la apropiación de reconciliación con el mundo a través del lenguaje:

El ejercicio de la poesía, la búsqueda verbal de finalidad desconocida, le iba desarrollando una extraña percepción por las palabras que adquieren un relieve animista en los agrupamientos espaciales, sentadas como sibilas en una asamblea de espíritus.

Para la mejor comprensión del arte poético-narrativo de Lezama imitaremos a sus apresurados lectores habaneros del año 66 centrando nuestra atención en su empleo peculiar del lenguaje erótico y contraponiéndolo al de un ingenioso autor de novelas verdes de comienzos de siglo, el español Joaquín Beldá.

8 Víctor Sklovsky, Teoria de la prosa. (Barcelona: Editorial Planeta, s.f.). 
II

La literatura erótica de todos los tiempos y latitudes conoce un abundante repertorio de fórmulas eufemísticas destinadas a eludir el nombre común de las partes sexuales o el acto de la cópula, ya por la referencia indirecta y oblicua, ya mediante el recurso a alguna figura de lenguaje. Muy a menudo el escritor procede a una singularización del objeto, separándolo de la propia serie y proyectándolo a una estructura heterogénea, o bien lo describe con fingida inocencia, como si ignorara de qué se trata y lo estuviese viendo por primera vez. En el Cancionero de burlas provocantes a risa y, sobre todo, en La lozana andaluza encontramos numerosas imágenes de este tipo: el miembro viril es "lanza", "garrocha", "'unicornio", "mano de mortero", "cirio pascual", " pedazo de caramillo", el órgano femenino, "pantano", “aduana", el semen, "suero", "engrudo"'; los testículos, "compañones"'; el acto sexual, "entrar en coso", etc. Con estas figuras eufemísticas, Delicado traza metáforas como "el hurón" que "caza" en la "floresta" o "decir dos palabras con el dinguilindón". En otros pasajes, los protagonistas del "retrato" aluden al sexo de forma tangencial recurriendo al empleo de perífrasis, pronombres demostrativos o adverbios de lugar.

En un ensayo célebre ${ }^{9}$, Roman Jakobson observaba con agudeza que la aplicación del eufemismo varía según el contexto: mientras en un medio habituado a la obscenidad el uso de tropos desempeña una función claramente singularizadora y actúa con mayor fuerza impresiva sobre el auditorio, en un medio cultural "elevado" - el de los lectores de un texto literario-la irrupción de la palabra cruda posee mucho mayor impacto. Si; por un lado, el repertorio del vodevil popular impone la regla de no mencionar jamás las cosas por su nombre, el bardo puede violar aposta la armonía del lenguaje poético y escribir, como Miguel Hernández "en los cojones del alma". En ambos casos epíteto crudo y eufemismo trasladan al lector o espectador a otra serie semántica y revisten al término desplazado de una envoltura nueva, obligándoles a detener la mirada en él. Un examen comparativo de los símiles y perífrasis eróticas de Paradiso y los de la novela de Belda nos ayudará a comprender el papel estrictamente regulador del contexto. ${ }^{10}$

La boscosa frondosidad del lenguaje de Góngora-su violenta distorsión sintáctica aunada a una fulgurante capacidad metafórica-es el eje vector del proceso de singularización erótica en Paradiso. El índice trastocador del poeta cordobés, su verso

\footnotetext{
9 "Sobre el realismo artístico", Véase Tbéorie de la littérature, ed. cit en nota 4.

${ }^{10}$ En La Coquito de Joaquín Belda encontramos numerosos ejemplos de este tipo de vodevil o astracanada tan popular en los teatros del Paralelo barcelonés o en el célebre Blanquita de México:
}

El repertorio del Salón Nuevo lo formaban obras de títulos ambiguos, que se prestaban a una interpretación maliciosa, por parte de algún malpensado: El bijo de Pura, Tres noches sin sacarla, Tomar por el atajo, y el gran éxito de la temporada, la obra cumbre del género, la genial Tortilla de almejas, pieza en seis cuadros que se decía escrita por un oficial del Consejo de Estado, y en la cual habia un personaje, banquero arriunado él, que en una escena de marcado sabor trágico, decía a gritos, parándose en el centro de la escena:

"Me persigue la justicia.

Todas las gentes me escupen.

¿Quieren chuparme la sangre?

Pues bueno, iQue me la chupen!

Véanse igualmente las escenas de las págs. 86-7, 90-2 y 94-5 de la misma obra. 
escurridizo, serpentino, permiten al novelista del siglo $\mathrm{XX}$ adueñarse del mundo complejo en que vive mediante la creación de un cuerpo verbal vivo y, por consiguiente, sensual. Del mismo modo que el juego erótico aplaza en la medida de lo posible el momento del orgasmo, el juego literario prolongará como un fin en sí la voluptuosidad de nuestra lectura. Erotismo y escritura barroca coinciden, así, como ha observado Sarduy, en virtud de una común disposición lúdica: el humor, el cubanísimo "choteo"' se infiltran en la metáfora lezamesca y tienden un puente de comicidad entre dos series dispares, organizan insólitas afinidades electivas. Los símiles eróticos de Paradiso abrazan en general el mismo radio de acción que sus restantes figuras-el de los manuales ilustrados de historia, geografía, pintura o ciencias naturales que marcaron con su impronta la imaginación omnívora del joven Lezama, con un neto predominio de las metáforas relacionadas con el mundo vegetal y animal. Pero el carácter furiosamente "retórico" del texto impone un cambio sutil en el uso del procedimiento: Lezama no se dirige a un público popular, habituado a llamar a las cosas por su nombre y para quien la ingeniosidad del autor se mide por su mejor o peor manejo de la perifrasis o el eufemismo; el lector de Paradiso se mueve en un universo estrictamente cultural, en los antípodas del "realismo" y precisamente por ello la introducción del término sexual común ocasiona una quiebra abrupta, semejante a un cortocircuito:

...cuidaba el patio un alumno de la clase de preparatoria que entonces era el final de la primera enseñanza, un tal Farraluque, cruzado de vasco semititánico y de habanera lánguida, que generalmente engendra un leptosomático adolescentario, con una cara tristona y ojerosa, pero dotado de una enorme verga.

A lo largo de la novela, en medio de una estructura supraretórica, puramente literaria, Lezama siembra maliciosamente vocablos como falo, verga, balano, glande, frenillo, vulva, canal o bolsa testicular. Con mayor frecuencia, cuando recurre a un tropo, no elimina del todo el sujeto referencial tanto cuanto éste mantiene su presencia en forma de adjetivo: "vela fálica", "espiral ascendente de la columna fálica", "cornalina fálica", "rabo fálico", "serpiente fálica", "bastón fálico", "coloso fálico", "dolmen fálico", etc. Otras veces, la metáfora lezamesca parte del nombre común para trazar una parábola imprevisible, que catapulta el sujeto de la frase a un predicado propio, ora del mundo natural o de los objetos creados por el hombre:

...el balano del Fronesis estaba flácido como una vaina secada por el sol.

...el falo de Vivo, como un enrollado parasol.

...el glande retraído esbozaba un diminuto cimborio.

ora, como ocurre más a menudo, a una perspectiva cultural-artística, histórica o mitopoética:

...la potencia fálica del guajiro Leregas reinaba como una vara de Arón.

...Leregas extraía su verga-con la misma indiferencia majestuosa del cuadro velazqueño donde se entrega la llave sobre un cojín breve como un dedal al principio, pero después como impulsado por un viento titánico, cobraba la longura de un antebrazo de trabajador manual. 
...colocando sobre la verga tres libros en octavo mayor, que se movían como tortugas presionadas por la fuerza expansiva de una fumarola. Remedaba la fábula hindú sobre el origen de los mundos.

En alguna oportunidad, Lezama invierte los términos de la ecuación poética y, en vez de trazar el arco comparativo a partir del vocablo sexual se sirve de éste como predicado de la metáfora:

...la espada encajada en la tierra como un phallus.

...honguillos, venenosos tan sólo para el hombre, semejantes a falos de glande albino.

Pero, como Góngora, Lezama favorece mayormente la aplicación de la imagen sustitutiva. El eufemismo sexual, especialmente fálico, recurre a veces al arsenal retórico de los autores de novelas verdes: cirio, espolón, lombriz ("el escándalo de las progresiones elásticas de su lombriz sonrosada"), colmillo, aguijón ("la rolliza longura de sus aguijones"), pico de gallo, fruta ("lupita no vaciló en esconder en su cuerpo la fruta que había hecho suya"), lanza, columna; otras, a la perifrasis: "el instrumento penetrante", "espíritu germinador", "dotación germinativa", "atributos germinativos", etc. La imagen nos vincula a trechos al mundo histórico o mitológico:

....aquel improvisado Trajano columnario.

...el encandilamiento del faro alejandrino del guajiro.

...la columna Luxor.

...lanza pompeyana en acecho.

...la agustiniana razón seminal.

...1a arrebatada gorgona chorreante del sudor ocasionado en las profundidades.

O el circunloquio serpentea con anillada lubricidad gongorina:

...el vuelco del líquido feliz.

...el llanto que le rodaba por el colmillo.

...la otra extensa teoría flácida.

..las dos ovas enmarañadas en un nido de tucanes.

...el casquete cónico de la cornalina.

...la fuerza muscular somnifera de la serpiente.

...el salto de la energía suprema. 
...1a transfiguración interrumpida.

La elisión característica del cordobés, florece en la selvática vegetación de Paradiso con riqueza y prodigalidad desconocidas por nuestra lengua desde hace más de tres siglos: las camas donde eslabona la divertida "cadeneta sexual" de Farraluque serán sucesivamente "cuadrado espumoso", "cuadrado gozoso"; Ios homosexuales pasivos, "cinedos con megacolon congénito"; las caricias de Roxana, "su incesante quehacer artesanal"; Lucía y Fronesis besándose, "dos orugas que se interrogaban con sus cuernecillos", el ano es, "circulo de cobre", "cráter de Yoculo", "cráter de Sneffels"; el escroto, "sombra anillada por Scartaris"," el señor del antifaz sodomizado por Farraluque, "su sumado contrario", "poderoso incorporador del mundo exterior", sujeto recipendiario; el coito, "suspensión donde los contrarios se anegan en el uno único", "toque central ígnito". El sexo femenino nos es descrito ya mediante imágenes del mundo animal: " araña gorda", "araña abultada"; ya del mundo vegetal o inorgánico: "crinaje o yerbazal picoteado por una siguapa", " gruta barbada", "'ondulaciones de un terreno carbonifero", " "yerbecilla del monte", "subterráneo al lado de la pradera oscura", etc.

La extensión del lenguaje de Lezama, esta encarnizada búsqueda suya de "una sustancia resistente enclavada entre una metáfora que avanza" y "una imagen final (que asegure) la pervivencia de esta sustancia" 12 , prolonga elásticamente el mecanismo comparativo a partir del término susutitutivo inicial, izándolo a un nivel supraretórico-retórica al cuadrado-en el que, como siempre, se cuela un deje de risa, de burla discreta:

...cuando precisó que el agujero de la lona cubría el círculo por el que se entraba al río de la fémina, el gallo de Eros anunció el alba de su aguijón posesivo", "los yerbazales, las escoriaciones, los brotes musgosos donde el nuevo serpentín del octavo día se trocaba en un honguillo con una pequeña corona planetaria en torno al glande de un marfil coloidal.

...en el mesón de Tablas podridas, en la fiestera, gaveta cilindrica, cochinilla, gruta manadora, estalactita de alcanfor, piedra pómez para el pico tenso del gallo dormido.

...la energía, rastrillada por el rencor, se volcó varias veces en las bahías, muy al descubierto, de la deseosa enigmática.

Contemplaremos ahora, para concluir, dos ejemplos del ars combinatoria lezamesca que nos ayudarán a descifrar, como en una pictografia del barroco, el signo distintivo de su procedimiento de singularización respecto al gongorismo inconsciente del novelista español:

...Ese encuentro amoroso recordaba la incorporación de una serpiente muerta por la vencedora silbante. Anillo tras anillo, la otra extensa teoría flácida iba penetrando en el cuerpo de la serpiente vencedora, en aquellos monstruosos

11 Julio Cortázar ha analizado estas referencias crípticas a Julio Verne en el ensayo que consagra a Lezama en $L a$ vuelta al dia en ochenta mundos.

12 Entrevista con Armando Alvarez Bravo en Orbita de Lezama Lima. 
organismos que aún recordaban la indistinció́h de los comienzos del terciario donde la digestión y la reproducción formaban una sola función. La relajación del túnel a recorrer, demostraba en la españolita que eran frecuentes en su gruta la llegada de la serpiente marina. La configuración fálica de Farraluque era en extremo propicia a esa penetración retrospectiva pues su aguijón tenía un exagerado predominio de la longura sobre la raíz barbada. Con la astucia propia de una gragura pirenaica, la españolita dividió el tamaño incorporativo en tres zonas, que motivaban, más que pausas en el sueño, verdaderos resuellos de orgullosa victoria. El primer segmento aditivo correspondía al endurecido casquete del glande, unido a un fragmento rugoso, extremadamente tenso, que se extiende desde el contorno inferior del glande y el balano estirado como una cuerda para la resonancia. La segunda adición traía el sustentáculo de la resistencia, o el tallo propiamente dicho, que era la parte que más comprometía, pues daba el signo de si se abandonaría la incorporación o con denuedo se llegaría hasta el fin. Pero la españolita, con una tenacidad de ceramista clásica, que con solo dos dedos le abre toda la boca a la jarra, llegó a unir las dos fibrillas de los contrarios, reconciliados en aquellas oscuridades.

III

Entre las novelas de Joaquín Belda escogeremos la que describe la vida y milagros de "la célebre e inconmensurable Coquito, reina de la rumba y emperatriz del cuplé" 13 .

Su autor pertenece a aquel grupo de escritores de comienzos de siglo que, aprovechándose del relativo liberalismo de la censura alfonsina en lo que concierne al sexo, cultivaron asiduamente, a veces con gran ingenio, la llamada novela verde, alcanzando algunos de ellos enorme popularidad. En mi opinión Belda sobresale entre todos por su sátira discreta de la sociedad hispana y, como vamos a ver, por la indole señaladamente barroca de sus imágenes y eufemismos. Aunque la intención social de La Coquito sea menos obvia que la de otras obras de su autor ${ }^{14}$, el lector puede espigar en ella una serie de observaciones que, con fino sentido del humor y sin el énfasis teatral del 98 , entroncan no obstante con la problemática de éste y su crítica general del país. ${ }^{15}$

El argumento de la novela es muy simple: la Coquito, vedette del Salón Nuevo madrileño-teatro especializado en un repertorio de astracanadas y números bailables de título ambiguo-vende su cuerpo al mejor postor después de la función, gracias a los celestinescos servicios de su propia madre, la pragmática y galdosiana doña Micaela. Entre los suspirantes se halla Julio González, llamado Julito, estudiante pobre que durante meses, a costa de grandes sacrificios, reúne peseta a peseta y duro a duro la cantidad, entonces astronómica, que fija la alcahueta. El mancebo, en el interín, alimenta la llama de su pasión con esporádicas visitas al Coliseo donde la bella cierra el espectáculo con un

13 La Coquito. Novela Picaresca. Ediciones Alegría, sin fecha. La novela de Belda está prohibida en España, y adquiri un ejemplar de la edición que cito en una porno-shop de la calle 42 de Nueva York frecuentada al parecer por un público hispanohablante.

${ }^{14} \mathrm{La}$ anciana peripatética de Las noches del botánico es una especie de Benina de Galdós, testigo de las estrecheces y ahogo de la pequeña burguesía madrileña. El discurso final del cura párroco ensalzando sus "virtudes' ' es una pieza de antología.

${ }^{15}$ La Coquito, pp. 77-8 y 146. 
número de baile con primicias' de estriptís. "Yo afirmo con toda solemnidad-escribe Belda - y si me equivoco que la Historia arroje sobre mis hombros toda la responsabilidad de la afirmación que estamos asistiendo, en esto de la rumba, a un acontecimiento de igual importancia y de mucha mayor trascendencia que la batalla de las Pirámides". Ante esta visión gloriosa, el "río vital" del mozo rompe los cauces y se desborda por "las campiñas" de los muslos con "riadas petroleras". Al fin la noche anhelada llega y la rumbera y el estudiante se éntregan el arduo, casi litúrgico ejercicio de una pasión que ocupa aproximadamente un tercio de la novela, en un in crescendo que, aunque sin el cambio de partenaire, evoca las hazañas de Farraluque en el capitulo VIII de Paradiso. La progresión dramática culmina en el momento en que la Coquito, armada de "un objeto extraño" de fabricación tudesca, acomete a la "fortaleza virgen" del mozo y, mientras este experimenta "una impresión de divorcio en sus carnes, como si un paraguas automático se hubiese abierto en el interior de su organismo y se empeñase en salir al exterior sin cerrarse", Belda se limita a comentar: "Una nueva vía de comunicación acababa de abrirse a viajeros posteriores en España, pais, según dicen, tan falto de ellos"'.

El lenguaje de Belda es sumamente inventivo y brillante: como los autores del repertorio teatral del Sálón nuevo, se dirige a un público cuyo apetito inextinguible de sítuaciones escabrosas se compensa con un ansia no menos voraz de perifrasis y eufemismos basados en una regla única: no llamar jamás al pan pan y al vino vino. Dicho principio impone al autor de obrạs verdes el uso continuo de símiles y tropos, destinados a atraer la atención del lector o espectador sobre el arte exquisito con que el escritor sortea el obstáculo de la expresión común y cruda. Como en las obras teatrales tipo el "Tenorio", en que el inconveniente de la falta de tensión dramática dado que el argumento es conocido de antemano, se contrapesa con una mayor atención del espectador en el montaje escénico y juego de los actores, el verosintil artístico de un géhero tan consabido y preciso como el que cultiva Belda le consiente lucirșe en cambio en el ejercicio de una retórica que se convierte así en el factor dínámíco de là obra, esto es, en su "signo diferencial". La rigidez y esquematismo del código implican por consecuència un margen muy amplio de improvisación en el que importa mucho menos el "que" que el "como". Aunque el almacén de trópos de Belda se aplica prefęrentemente al cuerpo humano y al acto sexual, es interesante observấ que su aficiớn metafórica se contagia a las demás descripciones de la novela y, a menudo, el puente de sus símiles, tendido sobre el abismo que separa a dos términos pertenecientes a series heterogéneas, es inmenso:

...le olía la boca a entierro de grajos.

...parecía (la negra) como un gigantesco mueble de ébano (...) algo así como si la Cibeles tomase un baño de tinta.

...fea como un paraguas sin varillaje completo.

...el sudor de ella, espesó y oliente a chirimoya soltera, me corría por el cuerpo como el óleó de una consàgración. 
...dos sonoros besos, uno en cada zapato, cayeron a los pies de la artista como dos rosas blancas arrojadas desde un palco proscenio.

Por haber sido escrita durante la Primera guerra mundial, la obra abunda en símiles e imágenes militares o alusiones a la marcha de los acontecimientos bélicos: "El, invadido por la espalda, como el Tirol y el Trentino"; "Clausewits decía que una de las maniobras más difíciles de la guerra era picar la retaguardia al enemigo"; "comparado con lo que el cuerpo de la chica tendría que aguantar (...) la toma de Lieja por el ejército de Von Kluck sería un almuerzo en la Bombilla," etc.; el temible "objeto"' con que la Coquito sodomiza a su galán es evocado asimismo en términos militares: "mientras el pueblo del Kaiser tuviese en su arsenal armas como aquélla, podría hipotecar a cañonazos el porvenir del mundo'.

A diferencia de Lezama, Belda sortea cuidadosamente la mención directa del acto o partes sexuales tanto cuanto dichos elementos se hallan siempre presentes en la mente de los lectores y son, a decir verdad, los auténticos protagonistas de la obra. Sus eufemismos adoptan de ordinario la forma de perifrasis: "los hemisferios de la fachada"; "el nutritivo botoncito", "la cordillera que rodeaba su vértice sexual", "ciertos recodos genéricos propiedad de la huésped", "el botón floreál que se alzaba en el centro de la roca," etć., transformados en imagen pasan a ser a menudo, como en Lezama, sujeto de una metáfora cuyo predicado parece extenderse elásticamente-simple pretexto del novelista para ampliar la materia verbal: los pechos de una cupletista serán ". dos ciruelas vaciadas por el picotazo de los pájaros"; idem. los de la Coquito, "dos divinos limoncillos; blancos como el nardo(que) se elevaban al cielo endurécidos y con el bótón del vértice lleno dé amenazas, como el pitón de un toro Miura" o, aún, "dos meloncillos a medio crecer, iguales, prietos, y con un ligero vaivén al andar, que hacia temblar los botoncillos del vértice, rosados como la calva de un senador limpio".

Los diversos aspectos y elementos del acto sexual son descritos en forma metafórica, a veces mediante sinuosos circunloquios de torcida sintaxis gongorina:

...un ratón que se había metido -oliendo a queso Roquefort - por el pașadizo śexual de la costurera.

...el surco violeta de sus ojeras (..) denotaba que el mancebo habia intentado consolarse de los desdenes del ser amado perturbando al silencio de su yo nocturno con manipulaciones indostánicas.

...el pararrayos acaba también en punta y con una calvicie que parece el pavimento de un salón de baile, èn cuyo centro hubiera un montículo puntiagudo.

...esperó a que él (...) como práctico que conduce la nave entre los esçollos dé la entrada del puerto, sacase a luz su imperativo categórico ${ }^{16}$, que parecía un faro vigilante entre las borrascass del océano. 
...su imperativo categórico (...) obedeciendo a la ley de la gravedad rindióse al suelo como el penacho de un jinete herido.

...la viuda encendió la luz y vio que por el techo, haciendo un taladro, penetraba un objeto extraño, terminado en punta, aunque algo roma, y que ella recordaba haber visto alguna vez antes de quedarse viuda. El objeto subia y bajaba en movimientos peristálticos, hasta que acabó por desaparecer.

En este último caso, Belda finge desconocer la realidad del pene, describiéndolo como algo insólito, que viese por primera vez e imponiéndonos así, conforme al precepto de Sklovsky, una "visión" del mismo, no un "reconocimiento".

Para una mejor comprensión del procedimiento escogido por Belda entresacaremos algunos párrafos y pasajes de las "variaciones sobre el tema" que, a lo largo de más de sesenta páginas de la obra, protagonizan el estudiante y la cupletista.

...¿Podría ella guardar en el divino estuche de su cuerpo aquella joya, que parecía fabricada en el pais de los gigantes? No tendría un límite la elasticidad de su criterio? (...) Como el indio se arrodilla ante un ídolo de la orilla del Ganges, así estaba ella postrada ante Julio (...) Coquito extendió las manos lentamente, y fue a coger con suavidad aquel cetro del imperio del mundo.

Concluido el acto, Julio, escribe Belda:

...se echó a sus pies, como uno de esos galgos de los cuadros ingleses (...) y allí por encima del charol de los zapatos, fue dejando sus besos como una ofrenda; algunas veces subía con ellos hasta la altura de la rodilla, pero bien pronto bajaba, como pajecillo humilde que en un momento de audacia se internase por las habitaciones reservadas de su reina, y saliese corriendo como un gamo al sentir el menor ruido (...), con timidez, como quien teme profanar el santuario de una imagen, alzó la bata con ambas manos y contempló el panorama interior (...) Avizorando el ojo y dirigiendo la visual hacia abajo, era un canalillo sutil lo que se veía, como un arroyo que corre entre montañas, y cuyo final, aunque no se veía, se presentia en un divino remanso de esplendor (...) fue una labor de ingeniero zapador la de limpiar de obstáculos el camino; no eran estos muchos: los pantalones y la bata únicamente; pero para la labor de miniaturista que él se proponía ejecutar, un papel de fumar sería manta de Palencia.

A continuación Belda se entrega a una elíptica descripción del cunningulus atestada de imágenes, figuras y símiles de todas clases, con un alarde de riqueza imaginativa y poética que no encontramos en ninguno de los escritores españoles de su tiempo con excepción, claro está, de Valle Inclán:

Con unción de peregrino que tras largo viaje llega al ara santa, Julio se arrodilló ante el cuerpo de Coquito. El mozo, (...) tuvo un rasgo de artista de circo: se echó las manos a la espalda, adelantó el busto, y sin más arma que ese apéndice sin hueso que Dios nos ha dado para que pronunciemos discursos y quitemos el pellejo a los amigos, comenzó su faena de maestro.

Fué primero un paseo reposado por las dos carreteras que desde las rodillas con- 
ducian al palacio central de los placeres; ese paseo era así como una fricción de vaselina que suavizase el camino, o como esos riegos que se hacen dos veces al día en las carreteras de las provincias vancongadas por medio de un carrito que lleva en su trasera un salto de agua.

Pero en este paseo, dondequiera que el paseante encontraba lugar ameno y propicio a detenerse, lo hacía con suma complacencia, y eran esos lugares aquellos en que el terreno se quebraba, doblándose sobre sí mismo, como en los vallecitos de las ingles, o en aquellas otras planicies donde la piel, por estar menos expuesta al sol y al aire, se suaviza, se sensibiliza hasta el infinito. Allí el arma renovaba sus ataques, aumentaba su velocidad, y su brío, para volver luego en un pianísimo, que era como una tregua, a su paso habitual por el resto del camino (...) Hay un bosque a la entrada de ciertos desfiladeros de la mujer, donde la sombra es grata y el descanso es orgía; en él, ¿cómo nó? se detuvo el estudiante, después de haber inspeccionado convenientemente todos los alrededores.

A la sombra de sus arbolillos, unos castaños de ramaje rojizo y sedoso riñó el artista una batalla que recordaba aquella o aquellas interminables de la Argona, en las que los guerreros no hacen más que tejer y destejer pasando varias veces por el mismo sitio.

A lo mejor el explorador, audaz en sus avances, se asomaba al valle profundo que dividia el bosque por el centro de sus laderas; pero no hacía más que asomarse, pues se retira al punto (...) Por la parte norte del bosque avanzaba la vanguardia del ejército invasor; parecía que por allí, sitio el más peligroso, como saben los inteligentes, iba a tener lugar el ataque a fondo; pero aquello no era más que una falsa alarma, pues bien pronto el enemigo se retiraba para volver a sus paseos de exploración. (...) Aquel chico era un maestro: la experiencia, profesora eterna del amor y de la vida, habia en él sido suplantada por un fino instinto que hacía dar a su apéndice bucal vibraciones de arpa eólica. El invasor penetraba en aquella cavidad con rimideces de educando, al principio; con audacias de piloto noruego después.

Se encontraba allí con uno de esos parajes que la Naturaleza se ha complacido en instalar en ciertos terrenos cercanos al mar o a tierras húmedas, una verdadera cueva de estalactitas, en que el agua cansada de gotear durante siglos, marcando el paso monótono de vida, se ha detenido en cristalizaciones poliédricas que por acabar en puntos recuerdan mucho a la mayoría de los dramas de Bernstein. La poesia ha hecho de estos lugares capillas de sus cultos idolátricos, (...) Aquella gruta, propiedad de La Coquito por la que, sin hipérbole, podía asegurarse que habian pasado más de mil turistas, parecía un lugar recién descubierto, un misterio cuyo velo acabase de rasgarse al conjuro de un aria de tenor, como en las óperas mitológicas. La frescura interior, la misma estrechez del lugar hablaban de algo virginal, de una primicia de fontana, oculta entre el ramaje de un bosque--del bosque por donde había merodeado poco antes el peregrino-, y que es para el 
viajero sorpresa y bendición. Y es que la imaginación y el agua de vegeto obran a las veces estos milagros.

Nueva o vieja, primicia o antiguiedad, estreno o reprise, el viajero comenzó una detenida inspección de los parajes más' recónditos de la cueva milagrosa, que bien pronto surtió su efecto. No hubo recoveco, no hubo alicatado de aquella maravilla del arte moro por donde no pasase con insistencia el estilete que Julio guardaba para estos casos y para humedecer el borde del papel Jean en que liaba los pitillos.

Había un sitio, allá en lo más alto del techo y ya donde éste empezaba a curvarse para formar la pared del fondo, que salía y brillaba más que el resto, algo así como esas pepitas de oro por encontrar una de las cuales pasan una vida de esclavitud los mineros de California, y por la que luego, ya fuera de la mina, se matan los hombres, como por una hembra que no se entrega más que al amante de manos ensangrentadas. Julito, o mejor dicho su apéndice, fijóse en ella, y comprendiendo que aquel era el punto flaco del enemigo, donde se ganan o se pierden las batallas, fuese a ella derecho como una bala y empezó una lucha en que todas las probabilidades de victoria estaban de su parte.

La "sorpresa", final de là temible rumbera nos vale igualmente un morceau de bravoure en el que la pirotecnia verbal y este humor del que tan cruelmente adolecen los mascarones de proa del 98 se combinan de modo delicioso al relatar la apertura de un nuevo túnel "a la civilización del mundo":

...el producto de los talleres alemanes inició un avance por entre dos promontorios

(...) Perderse por un atajo, por el que nadie ha pasado nunca tiene sus inconvenientes (...) pero tiene también sus encantos, y entre ellos no es el mejor el de abarcar con la vista panoramas que nadie ha contemplado y que se ofrecen a nosotros con todo el encanto de lo virginal (...) El chico (...) sentía en su interior una cosa muy extrafia (...), una impresión así como si tomando un baño, por un fenómeno de física empezase a internarse en su organismo toda el agua del mar (...). Era una introspección: la piel recogiéndose para adentro, cual un paraguas que se cierra y ya nunca más va a abrirse (...). Oyóse el único grito de queja; los demás fueron ya francas voces de delicia, como un coro angélico (...); el producto de la fabricación alemana habia desaparecido tơdo él-no medía más que 26 centímetros-de la vista de los mortales y hubiera sido inútil buscarlo por el suelo, ni debajo de los muebles; ¿Dónde estaba? Adivinanza (...) Lo ciertó era que, como el cuerpo humano no se dilatase de pronto, creando órganos nuevos, alli no podía hacerse más de lo que se habra hecho.

\section{IV}

Concluiremos el díptico contrastado entre el librillo de Belda y la extraordinaria creación de Lezama precisando que no se trata de un caso de influencia, como la polilla erudita, en su afanosa búsqueda de fuentes, se precipitarła a afirmar, sino de una coincidencia originada por el proceso interno de la escritura. Por prurito de conciencia consulté no obstante con Lezama y recibí una respuesta escrita de la que reproduciré estas breves, 
significativas líneas: "En relàción con el otro extremo de su carta, nunca he leido esa obra que usted me cita, ni creo que sea nécesario más para la lectura de ese capitulo VIII, que lo que allí se muestra. Algunos versículos de Las Leyes del Manú y sobre todo el Kamasutra (capítulo dedicado al Opoparika o unión bucal) leídos en la niñez y mantenidos con sensual relieve por la memoria. Los únicos libros de pornografía que he leido son la Biblia (Génesis) y Platón. En realidad las influencias literarias no son lo fundamental en mi obra, sino la aparición del súbito, un súbito de apoderamiento y realización". ${ }^{17}$

Resumiendo: míentras el gran escritor cubano se sirve de Góngora como el referente que debe permitirle la apropiación de la realidad-de la que el erotismo es parte-por medio del lenguaje, el ingenioso novelista español gongoriza malgré lui a partir del momento en que se ve obligado a recurrir al uso de elipses y eufemismos para imponer en sus lectores "su marca particular". La distinta calidad de los públicos a quienes se dirigen explica el empleo o rechazo del vocablo crudo según la lógica peculiar-y en apariencia paradójica-del contexto. Por encima de todo nos revela que el encuentro con Góngora-ya sea voluntario o inconsciente-puede desempeñar en la narrativa hispana del siglo XX un papel similar al influjo de Joyce en el mundo de habla inglesa. Unido al redescubrimiento por Borges del prodigioso juego literario cervantino es la demostración válida que, tras un eclipse de más de tres siglos, la novela en lengua castellana ha hallado la encrucijada perdida, la conjunción imprevista de su resurrección: la que a su manera ejemplarizan Góngora y Cervantes-audaz incursión en la realidad del mundo que misteriosamente se transmuta en aventura del proceso creativo del escritor. 
